\title{
Spatial structure transformation of Ulan-Ude city suburbs
}

\author{
Aldar Badmaev ${ }^{1}{ }^{*}$, and Marina Motoshkina ${ }^{1}$ \\ ${ }^{1}$ Baikal Institute of Nature Management SB RAS, Sakhyanovoy str., 6, 670047, Ulan-Ude, Russia
}

\begin{abstract}
The article analyzes the processes of suburbanization and transformation of the spatial structure of the city of Ulan-Ude. On the example of intensive growth of the suburb, modern trends of socio-spatial stratification of resettlement, caused by socio-economic and historical factors of development, are clearly seen.
\end{abstract}

\section{Introduction}

The growing urbanization and intensification of life leads to a constant increase in human needs, the satisfaction of which is an important factor in the further development of society. In this regard, it is necessary to create conditions that include a range of service industries. Thus, an analysis of the development of the territories of microdistricts and suburban settlements of the city of Ulan-Ude was necessary. The scientific approach from the point of view of economic and social geography revealed some features of active industrialization around Ulan-Ude, where workers' settlements grew up, most of which later merged with the urban district. The causes of mass migration from villages to the city and suburban areas are examined, as a result of which there was an unauthorized development of territories that led to a violation of the law and the modern look of the city of Ulan-Ude. In connection with the increase in the development of territories, social and environmental problems have increased.

\section{Research methods and materials}

The methodological basis of the study is the approaches to determining the size of a suburban area, presented in the works of E. B. Alaev, V. A. Kamensky, M. O. Khauke, W. Christaller, G. M. Lappo and others. The research was carried out on the basis of a systematic approach using cartographic, comparative geographical, and statistical methods, analysis of documents and stock materials of organizations and institutions, and literary sources; description and classification, logical modeling, and evaluation. The method of geoinformation research was widely used, which made it possible to simplify the visual analysis of maps and automate traditional cartographic research methods: cartometric measurements, joint analysis of maps of different scales

\footnotetext{
*Corresponding author: badmaev@binm.ru
} 
By distribution, workers from all over the USSR arrived to Ulan-Ude and its suburbs, for which workers' settlements and microdistricts were built (LVRZ, Steklozavod, Silikatny, Zagorsk, Vostochny, Airport and Sokol, etc.) together with all the city infrastructure necessary for a full life.

\section{Prconditions for the suburban areas growth}

Along with the decline of agriculture and the development of the capital of Buryatia, UlanUde, migrants from all over the republic and neighboring regions came for permanent residence [1], [2], [3]. Along with the indigenous townspeople, the former rural residents began to actively develop the nearest suburban territories. Having no funds to buy real estate, the newly made citizens were forced to build up a cheaper suburb. Ulan-Ude and Ivolginsky district could not cope with the sudden influx of population and could not adequately respond to the growth of suburban areas. As a result, most of the new suburban territories are built up spontaneously without any necessary engineering (multi-lane roads, water supply, sewage, district heating, etc.) and social (schools, kindergartens, clinics, large shops, sports facilities, etc.) infrastructure, not to mention landscaping and other improvements.

The built-up part of Ulan-Ude and its suburbs, for the period under review (2001-2019), grew to the West (the left bank of the Selenge river); to the South ("100-th" microdistricts and the township of Nizhny Sayantui); to the South-East (Zabaikalsky, Svetly, Raduzhny, Energetic, Tayozhny, and Impulse townships); to the North-East (townships of Verkhnyaya Beryozovka, Kumyska, Solnechny, Zelyony (Old and New Zelyony), Zelenkhoz, etc.) .

Over the past 20-25 years, processes have occurred in the suburbs of Ulan-Ude that are close to the concepts of suburbanization [4] and urbanization [5]. Suburbanization may lack social infrastructure (shops, schools, etc.) and places of employment. This is just characteristic of most of the Ulan-Ude suburbs. To a lesser extent, the ongoing processes can be attributed to the concept of urbanization, when the townspeople (for the most part already having housing in the city) move to a rural area adjacent to the city, but continue to lead an urban lifestyle.

It should be noted that in 1998 Federal Law No. 66-FZ of 04.15.1998 "On Horticultural, Vegetable Gardening and Dacha Non-Profit Associations of Citizens" [6] was issued, according to which plots were allocated in the territories of villages or outside them, with the right to erect a residential building, but without the right to register accommodation in it. The right to erect housing belonged to garden and country land plots, which were distributed in the newly created garden and dacha non-profit partnerships (GNP and DNP) [7]. This law did not immediately, but contributed to the explosive growth of private construction in the suburban area of Ulan-Ude. Most of the land was allocated on former agricultural lands taken out of business and re-registered in residential areas after the collapse of the agricultural complex in Buryatia. Another part of the land went for development in the forest. As a result, today dozens of non-profit associations of citizens have formed, which have wrapped a tight ring around the capital of Buryatia.

According to the General Plan, the development prospects of the urban district "City of Ulan-Ude" in connection with territorial development were given to the western (left bank of the Selenge river) and southern suburban territories of Ulan-Ude, which have grown most intensively since the beginning of this century. When calculating the built-up territory, GNP and DNP, which are included in the territory of townships, were taken into account. The western part of Ulan-Ude borders on the Ivolginsky district, which, due to the massive development of its eastern territories adjacent to the capital of Buryatia, more than doubled its population - from 25.3 thousand people in 2000 up to 52.2 thousand people in 2017. 
In the Western part of Ulan-Ude (left part) considered 10 locations, 7 of which are in the Ivolginsky district (the nearest inhabited localities of the region whose distance from the centre of the city does not exceed $20 \mathrm{~km}$ ): Poselye, Huzha, Khoito Beye, Nur-Selenie, Nizhnyaya Ivolga, Sotnikovo and Gurulba; and 3 - Ulan-Ude: Soldatsky, Istok and Tulunzha (Fig. 3). The townships of Zarechny, Airport and Sokol have not changed much and remain stable. In the southern part, 3 localities and all the hundredth districts of the South are considered. Satellite images of some localities begin in 2001, and another part in 2006. Nevertheless, after analyzing the work carried out, an objective picture of changes in the built-up part of the Ulan-Ude suburb can be traced

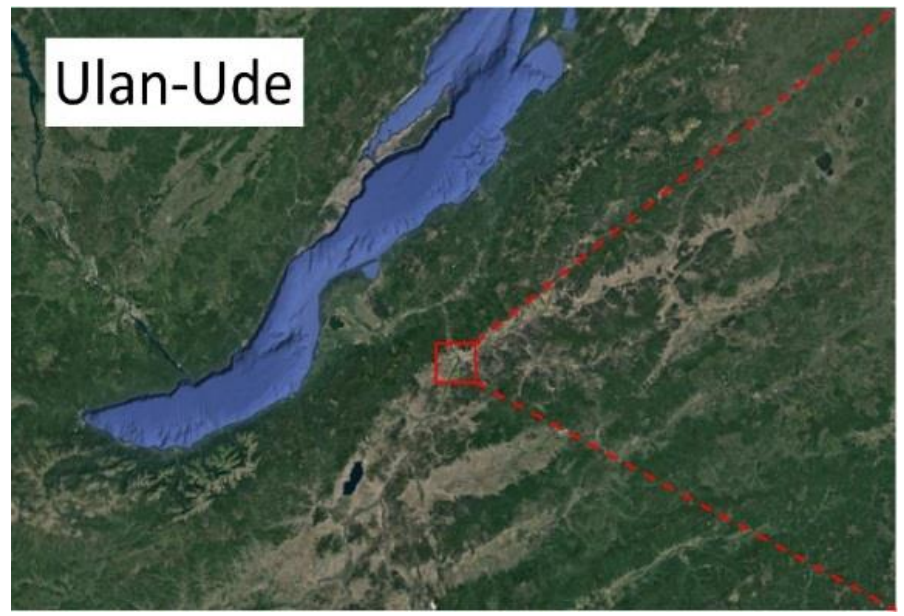

Fig. 1. Ulan-Ude frame.

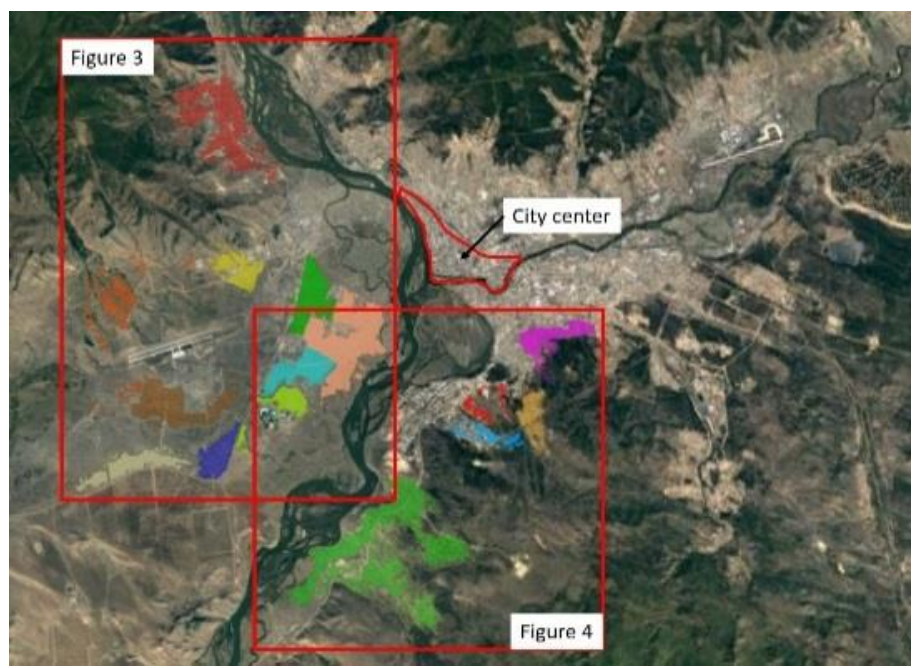

Fig. 2. Ulan-Ude suburbs' frames. 


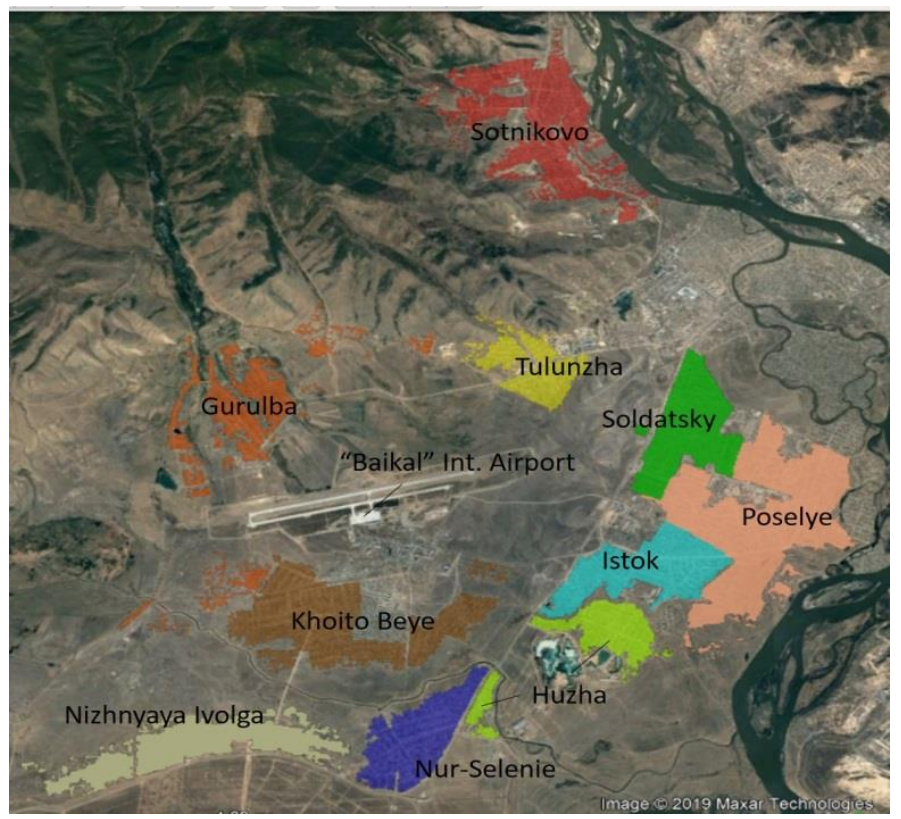

Fig. 3. Western suburban settlements and microdistricts of Ulan-Ude (compiled by the Aldar Badmaev on the basis of the Google Earth Pro service [8]).

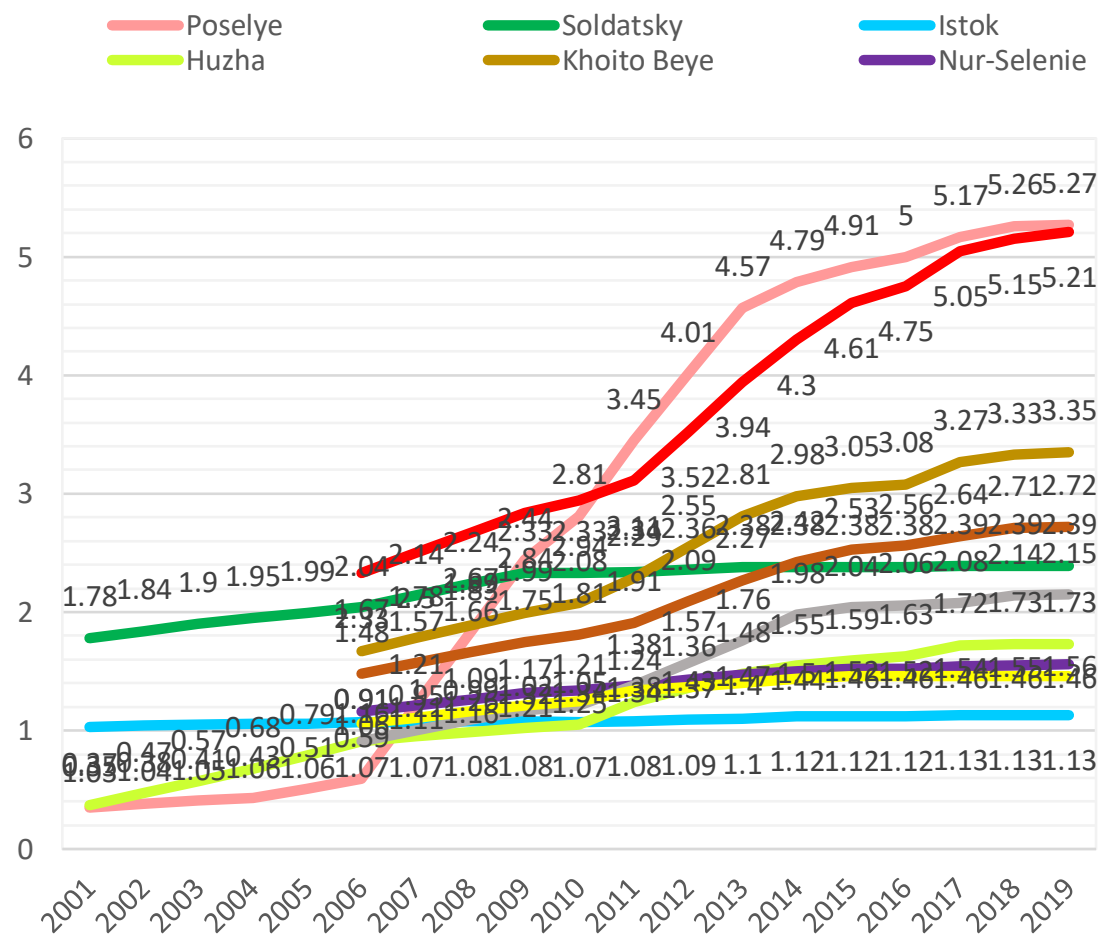

Fig. 4. Dynamics of growth of the built-up area of microdistricts and suburban settlements in the Western part of Ulan-Ude (2001-2019), $\mathrm{km}^{2}$ (compiled by Aldar Badmaev). 


\section{The population growth dynamics}

In 2002, the population of Selenge river's left bank suburban settlements was 18.9 thousand people [9], [10]. Rosstat data for 2010 is currently not relevant. statistics are not kept for some districts, including 100th microdistricts in this regard, built-up territories were used as an up-to-date indicator of suburban growth. On average, the density of single-storey settlements varies in the area of $1500-2000$ people $/ \mathrm{km} 2$, in rare cases even reaching up to 3000 people $/ \mathrm{km} 2$ of built-up territory. Thus, you can calculate the approximate number of inhabitants in a locality. The total built-up area shown in Fig. 3 localities for $2019-27$ $\mathrm{km} 2$, multiplying this area by the average density (2000 people $/ \mathrm{km} 2$ ) we get an approximate population of 54 thousand people over 17 years, the population has almost tripled ( 2.85 times) by more than 35 thousand people. For correct assumption, you need to wait for the census data in 2020, and then compare these calculations with them.

\section{The area growth dynamics}

The built-up territories of Soldatsky and Istok grew the least, which were already relatively densely built up, were clamped by their natural and administrative borders, and opportunities for further growth were exhausted by the mid - and late 2000s. Small growth rates in Tulunzha and Nur-Selenie. The average growth rate in villages in Khoito Beye, Gurulba, Nizhnyaya Ivolga and Huzha. High growth rates are observed in the villages of Poselye and Sotnikovo. The village of Sotnikovo grew 2.2 times (from 2.33 to $5.21 \mathrm{~km}^{2}$ ) during the study period from 2006 to 2019.

Explosive nature of building growth is observed in the village of Poselye in the Ivolginsky district, whose territory grew 9 times between 2006 and 2019, and 15 times between 2001 and 2019 (from 0.35 to $5.27 \mathrm{~km}^{2}$ ). The area of the village itself, however, remained almost unchanged. The village grew from a single street, which was located in the middle of arable land and hay fields, to a giant continuous settlement, connected with the neighboring villages of Soldatsky, Istok, and Huzha (in 2009). And, if, from 2001 to 2006, the growth rate of development was insignificant 8-15\% annually, then from 2007 to 2009 , the village each year grew by an area equal to the Settlement of the sample in 2006. In other words, the built-up area of the village has quadrupled in three years. Such growth rates continued until 2013 inclusive, and then, from 2014, the rate decreased (Fig. 3). We can assume that the rapid growth of this particular village is due to several factors: first, the territory is flat, treeless and dry; secondly, the village is located relatively close to the center of Ulan-Ude, almost opposite-through the Selenge river; and thirdly, the administration of the Ivolginsky district strongly promoted the creation of the DNPs and GNPs within the boundaries of the village.

In the southern part, the hundredth microdistricts are geographically combined into three blocks (Fig. 4): 1) multi-storey 102, 104, 105 and 106 microdistricts; 2) multi-storey $110,111,112,113$, and low-rise 125 and 126 microdistricts; 3) low-rise housing estates from 117th to 124th. Two settlements were also considered: Novaya Komushka and Zabaykalsky (Zverosovkhoz), as well as the village of Nizhny Sayantuy (Vakhmistrovo). They are all different in territory, landscape, infrastructure development, etc. However, they all tend to grow.

The construction area of multi-storey housing estates is compensated by high density. Between 2001 and 2019, the "quiet" hundredth (multi-storey) quarters grew into new large housing estates, an increase of 6.5 times. 117-124th microdistricts grew slightly less. They have grown 5.6 times over the same period. 


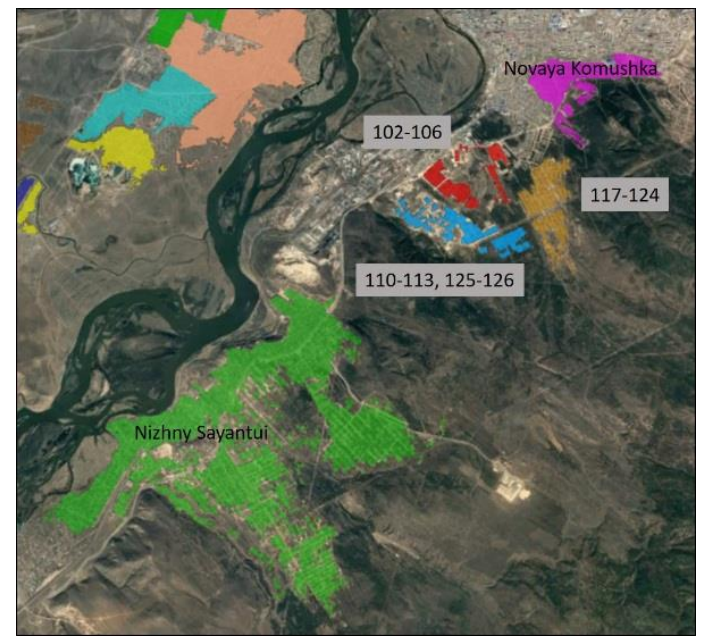

Fig. 5. South suburban towns and neighborhoods of the city of Ulan-Ude (compiled by the Aldar Badmaev on the basis of the Google Earth Pro service [8]).

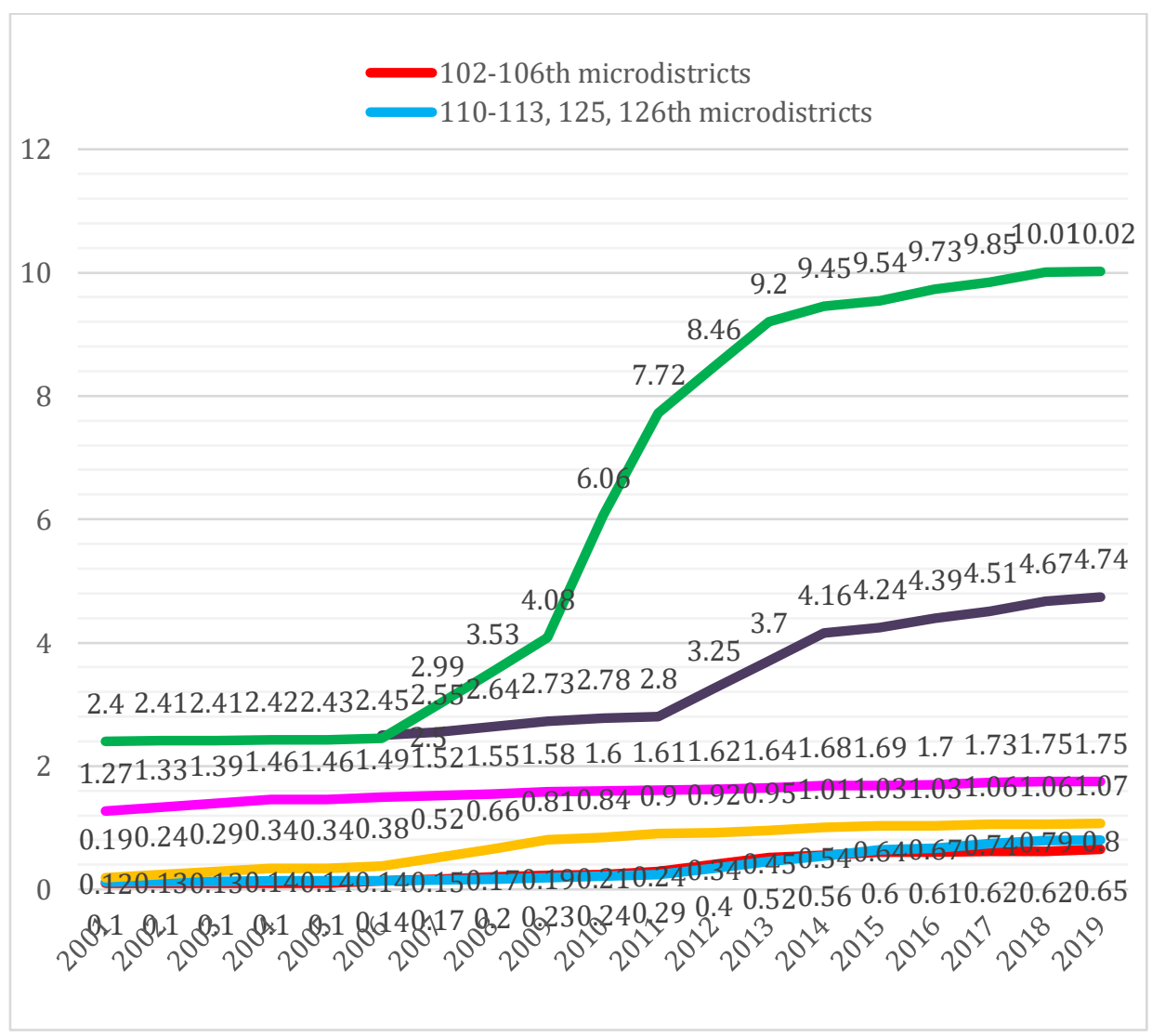

Fig. 6. Dynamics of the built-up area of microdistricts and suburban settlements of the southern part of the city of Ulan-Ude (2001-2019), $\mathrm{km}^{2}$ (compiled by Aldar Badmaev). 
In comparison, the Novaya Komushka settlement shows low growth rates in the development of territories. Presumably this is due to the fact that Novaya Komushka is framed by a railway from the north, bordering the village of Gorky from the west, and a mountain range from the south. Nevertheless, due to the proximity to the city center, the village slowly continues to grow, building up the uncomfortable northern slopes of Mount Komushka.

The large Zabaikalsky village, which has no neighbors and is limited only by the landscape, continues to grow. So, in 2012-2014, the built-up area of the village grew by 1.5 times. The active growth of the village is hindered by a large forest and transport inaccessibility. Nizhny Sayantui, which over the past 18 years has grown 4.1 times, reaching a built-up area of $10 \mathrm{~km}^{2}$, can be considered the largest in terms of the building area and the fastest growing settlement. The peak of mass development was 2007-2014. It is noteworthy that the potential for rural growth has not yet been exhausted.

\section{Conclusion}

Based on the foregoing, we can conclude that the peak of growth of the suburban territories of Ulan-Ude occurred in the period from 2007 to 2014, largely due to private individual development. At the same time, one should pay attention to the fact that more often the most accessible in time and transport areas are developed, which are economically advantageous from the point of view of using local labor resources and social infrastructure, but are not always the most valuable in recreational terms, environmentally friendly, physiologically comfortable and aesthetically attractive, since this system of territory development took place spontaneously. Since 2007, the "Maternal capital" program began, which allowed many families to purchase affordable housing with a land plot, but at the same time, social and economic efficiency is very low, and environmental damage is high. The dynamics of the construction of multi-storey houses of the hundredth microdistricts of Ulan-Ude shows that a sharp increase in complex development began in 2012, and continues to this day, slowing down slightly in 2017-2018. The growth in the supply of comfortable apartments began after the mortgage boom in the early 2010s.

In connection with the growth of the suburbs, a number of problems appeared. This is the lack of the necessary urban infrastructure and the difficulty of bringing it up in the future, as the existing buildings will interfere with the construction of wide roads, social facilities, communications and landscaping. The rapid growth of the suburbs and the load on public suburban transport provoked the motorization of its population, which caused an unprecedented load on the roads. Daily pendulum migration, in addition to intra-city traffic jams, provoked suburban traffic jams as well. For residents of new residential low-rise areas, these places are just a place to spend the night. For everything else: work, study, treatment, leisure, shopping and other things - residents of the suburbs are forced to travel to the city center.

This work was carried out as part of the state assignment "The role of the Asian part of Russia and neighboring territories in the spatial development of the country in modern geopolitical conditions", AAAA-A19-119060390027-8.

\section{References}

1. N.R. Zangeeva, A.G. Badmaev, V.G. Ayusheeva, Problems of sustainable development of the region: IX school-seminar of young scientists of Russia: materials of the report, 32-36 (2019) 
2. A.G. Badmaev, Public geography in a changing world: fundamental and applied research: international materials of scientific conference as part of the $\mathrm{X}$ annual scientific Assembly of the Association of Russian geographers-social scientists, 86-92 (2019)

3. A.V. Kozulin, City and village in the context of globalization (on the example of the Republic of Buruatia: materials of an international seminar, 80-82 (2009)

4. Encyclopedic Demographic Dictionary. [Electronic resource]: official website. https://rus-demography-dict.slovaronline.com/1232

5. Encyclopedic Demographic Dictionary. [Electronic resource]: official website. URL: https://rus-demography-dict.slovaronline.com/1085

6. Federal law of April 15, 1998 N 66-Ф3 "On horticultural, vegetable garden and dacha non-profit partnerships of citizens". [Electronic resource]: GARANT System: http://base.garant.ru/12111288/\#ixzz640KgLnjx

7. M.A. Motoshkina, B.S. Norboeva, D.M. Ayusheeva, Journal Successes in modern natural science, 1 104-110 (2019)

8. Map Service Google Earth [Electronic resource]: official website. https://www.google.com/intl/ru/earth/versions/

9. 2002 All-Russian Population Census. [Electronic resource]: official website. http://www.perepis2002.ru/ct/html/TOM_14_02.htm (date of the application: 17.09.2019).

10. State Statistics Committee of the Russian Federation. State Statistics Committee of the Republic of Buryatia (Ulan-Ude, 2003)

11. 2010 All-Russian Population Census. [Electronic resource]: official website. https://www.gks.ru/free_doc/new_site/perepis2010/croc/perepis_itogi1612.htm 